\title{
REVIEWS
}

\section{Causes of Hypoxemia in COVID-19}

\author{
Zh. A. Donina ${ }^{a}$ * \\ ${ }^{a}$ Pavlov Institute of Physiology, Russian Academy of Sciences, St. Petersburg, Russia \\ e-mail:zdonina@mail.ru
}

Received September 21, 2021

Revised October 13, 2021

Accepted October 18, 2021

\begin{abstract}
The global pandemic of a new coronavirus disease (COVID-19) has posed challenges to public health specialists around the world associated with diagnosis, intensive study of epidemiological and clinical features of the coronavirus infection, development of preventive approaches, therapeutic strategies and rehabilitation measures. However, despite the successes achieved in the study of COVID-19 pathogenesis, many aspects that aggravate the severity of the disease and cause high mortality of patients remain unclear. The main clinical manifestation of the new variant of SARS-CoV-2 virus infection is pneumonia with massive parenchymal lesions of lung tissue, diffuse alveolar damage, thrombotic manifestations, disruption of ventilation-perfusion relationships, etc. However, symptoms in patients hospitalized with COVID pneumonia show a broad diversity: the majority has minimal manifestations, others develop severe respiratory failure complicated by acute respiratory distress syndrome (ARDS) with rapidly progressing hypoxemia that leads to high mortality. Numerous clinical data publications report that some COVID pneumonia patients without subjective signs of severe respiratory failure (dyspnea, "air hunger") have an extremely low saturation level. As a result, there arises a paradoxical condition (called "silent hypoxia" or even "happy hypoxia") contradicting the very basics of physiology, as it essentially represents a severe life-incompatible hypoxemia which lacks respiratory discomfort. All this raises numerous questions among professionals and has already ignited a discussion in scientific publications concerned with the pathogenesis of COVID-19. Respiratory failure is a complex clinical problem, many aspects of which remain controversial. However, according to the majority of authors, one of the first objective indicators of the clinical sign of respiratory failure are hypoxemia-associated changes in external respiration. This review addresses some possible causes of hypoxemia in COVID-19.
\end{abstract}

DOI: $10.1134 /$ S0022093022010070

Keywords: coronavirus infection (SARS-CoV-2), cytokine storm, hypoxemia, acute respiratory failure

\section{INTRODUCTION}

In late 2019, the People's Republic of China experienced an outbreak of a new coronavirus infection with an epicenter in Wuhan City, Hubei
Province. On February 11, 2020, the World Health Organization (WHO) defined the official name of the infection caused by the new coronavirus as COVID-19 ("Coronavirus disease 2019”). On February 11, 2020, the International 
Committee on Taxonomy of Viruses assigned the infectious agent an official name SARS-CoV-2 [1].

Coronaviruses (Coronaviridae) are a large family of RNA-containing viruses that can infect both animals and humans. In humans, coronaviruses can cause a range of diseases, from relatively mild acute respiratory infection (ARI) to severe acute respiratory distress syndrome (ARDS) [2, 3]. Large-scale studies have found that airway epithelial cells and mucosal immune cells are the first to become infected. Infected cells cause uncontrolled cascade expression of proinflammatory cytokines, chemokines and other mediators of the acute phase response, forming a "cytokine storm", an excessive immune response to infection [4-6].

COVID-19 differs from other forms of viral infections in that this variant of coronaviruses targets mainly the lungs, which is due to its tropism to lung tissue [7, 8]. To date, it has been shown that respiratory complications owing to a high sensitivity of the lungs to SARS-CoV-2 virus are the main mortality factor in critically ill COVID19 patients [9-11]. The reason for this sensitivity is that type II alveolar epithelial cells have a high level of expression of angiotensin-converting enzyme 2 (ACE2), which is a receptor for SARS$\mathrm{CoV}-2$, and type II transmembrane serine protease (TSP2), which promotes virus binding to ACE2 and penetration into the cell [12-14]. The available data indicate that ACE2 and TSP2 expressed on the surface of various airway, esophageal, intestinal, cardiac, adrenal, bladder, brain, and endothelial cells, as well as macrophages, may cause multiple organ failure [4, 7-12, 1521].

As follows from the recent publications [2225], patients admitted to an intensive care unit with severe ARDS and diagnosed with COVID19 had a very low saturation level. However, despite the severity of life-incompatible hypoxemia, some patients had no signs of ARDS (tachypnea, dyspnea, "air hunger"). Subsequently, especially in elderly patients, there was a sharp and sudden deterioration of the condition, requiring emergency resuscitation measures. For example, a clinical observation report indicates that in a 64-year-old patient with a positive coro- navirus 2 (SARS-CoV-2) test and ARDS progression, the saturation $\left(\mathrm{SpO}_{2}\right)$ measured by pulse oximetry was $68 \%$, whereas the arterial oxygen tension $\left(\mathrm{PaO}_{2}\right)$ was $37 \mathrm{~mm} \mathrm{Hg}$ with normocapnia $\left(\mathrm{PaCO}_{2} 41 \mathrm{~mm} \mathrm{Hg}\right)$. In another, 74-year-old, patient, also with a confirmed SARS-CoV-2 result, during face mask oxygen breathing, $\mathrm{SpO}_{2}$ was $62 \%$, while $\mathrm{PaO}_{2}$ was only $36 \mathrm{~mm} \mathrm{Hg}$. However, these patients had no complaints about breathing difficulties. From this, it follows that low saturation in the absence of visible respiratory discomfort is, in many cases, typical for most patients with COVID pneumonia [22, 26].

It should be noted that pulse oximetry $\left(\mathrm{SpO}_{2}\right)$, which is usually applied in medical practice for non-invasive monitoring of hypoxemia, reflects only hemoglobin oxygen saturation $\left(\mathrm{HbO}_{2} \%\right)$ and thus mismatches the true partial oxygen pressure in arterial blood $\left(\mathrm{PaO}_{2}\right)$ [27]. However, according to the established ideas, the determinative factor of oxygen supply to tissues is not $\mathrm{HbO}_{2} \%$, but $\mathrm{PaO}_{2}$ in $\mathrm{mm} \mathrm{Hg}$. In compliance with the physiological principles, oxygen dissociation from hemoglobin into blood depends primarily on the position of the oxyhemoglobin dissociation curve (ODC), which has a sigmoid shape, as well as on the oxygen-carrying capacity of blood, blood flow rate, temperature factor, etc. [28]. For example, hypocapnia and respiratory alkalosis resulting from hyperventilation (tachypnea, hyperpnea) shift the dissociation curve leftward and thus increase hemoglobin affinity for oxygen, impeding its getting into blood. This accounts for a higher $\mathrm{SpO}_{2}$ level at a very low $\mathrm{PaO}_{2}[29,30]$.

As seen from the above clinical examples, regardless of measurement methods-be it a noninvasive (pulse oximetry) or invasive $\mathrm{PaO}_{2}$ determination in arterial blood, patients with COVID-19 pneumonia develop hypoxemia. Recently, in publications of many authors, the presence of hypoxia without appropriate signs of respiratory discomfort has been defined as "silent hypoxia" or "happy hypoxia" [22, 23, 31, 32]. The reports on "mysterious hypoxia" or "asymptomatic hypoxia" have risen a wide discussion in scientific publications covering in the light of the established pathophysiological mechanisms the causes of ARDS absence in severe hypoxia at the early stage of COVID-19 [31, 33, 34]. It has been 
repeatedly shown in numerous studies that hypoxia progression in COVID-19 patients at the early stage of the disease occurs at the normal $\mathrm{PaCO}_{2}$ level (normocapnia), which does not appear to be a sign of respiratory dysregulation $[22,23,35]$. However, hypoxia is known to cause hyperventilation leading to hypocapnia that inhibits central (medullary) chemoreceptors. As a result, the ventilatory response to hypoxia subsides, thus explaining the absence of respiratory discomfort (dyspnea) in hypoxia. In this case, it is a respiratory dysregulation that is concerned. However, since ARDS develops at elevated $\mathrm{CO}_{2}$ levels (hypercapnia), the corresponding symptoms of respiratory dysfunction may apparently show up at later stages of the disease, when, against the background of hypoxia and hypercapnia, critical respiratory failure develops, i.e. impaired respiratory biomechanics, increased airway resistance, disrupted ventilation-perfusion relationships and pulmonary circulation, altered structure of the alveolar-capillary membrane, thromboembolism, etc. [22, 33, 36].

It should be noted that respiratory failure, including latent respiratory failure, is a complex clinical problem, many aspects of which remain debatable. Hypoxemia is considered to be one of the objective indicators of respiratory failure [37].

When discussing the potential mechanisms of hypoxia in COVID-19, one should consider the direct effect of SARS-CoV-2 virus on its cellular receptor (APF2), which is expressed in sensory cells of the carotid body, reducing the sensitivity of glomus cells to oxygen deficiency [38, 39]. It follows that one of the possible causes of hypoxemia in COVID-19 patients may be inhibition of peripheral chemoreception [40-42]. Here, an important practical question arises about the amount of APP2 and TSP2 in the carotid body that suffices for SARS-CoV-2 invasion into cells. The presence of APP2 in the carotid body was detected by immunoblotting [43, 44], but other authors, based on the results of immunohistochemical studies of the mouse carotid body, suggest only a minimal expression of the APP2 receptor therein, in contrast to its massive expression by epithelial cells of the lungs, intestine and kidneys [40]. Therefore, the issue of the degree of involvement of the peripheral respiratory regula- tion in the reflex mechanisms of hypoxemia development in COVID-19 has not been solved definitively as yet. However, reflex regulation does not rule out the direct influence of humoral shifts on the respiratory center. Possible neuroinvasion of SARS-CoV-2 into the CNS is considered to be the cause of hypoxemia, although the exact localization of infected structures in the areas responsible for respiratory regulation and controlling respiratory sensations still remains largely undetermined [41, 45-47].

At the same time, the related coronaviruses SARS-CoV and MERS-CoV have been found in the brainstem respiratory neurons, leading to fatal outcomes due to the development of severe respiratory failure [48-50]. It is quite likely that similar structures and neurotropism-based infection mechanisms that were found for other coronaviruses can be applied to SARS-CoV-2 equally well [41, 42, 51-53].

Damage to the endothelium and lung microcirculatory bed is an important part of COVID-19 pathogenesis because SARS-CoV-2 infects lung endothelial cells expressing APF2 [54]. It was established that acute inflammatory process and endothelial damage caused by the imbalance between procoagulant and fibrinolytic activities, elicits intravascular microthrombosis in smallcaliber pulmonary vessels [55]. Increased thrombosis has been detected in COVID-19 patients, while postmortem examination revealed massive damage to alveolar microcapillaries, edema and thickening of the alveolar-capillary membrane, pulmonary capillary occlusion, presence of large thrombi causing pulmonary artery thrombosis [56]. These data indicate that with a severe clinical course of COVID-19, thromboembolia is the most frequent complication that contributes to pulmonary vascular obstruction, disrupted ventilation-perfusion relationships, and hypoxemia development [57].

Fibrin and thrombin deposition occurs mainly in the pulmonary microvasculatory bed, being a factor that promotes the development of ARDS and coagulopathy in patients dying from COVID-19. Since the transition of oxygen from alveolar air to the blood of pulmonary microvessels occurs by diffusion across the alveolar-capillary membrane, its thickening, as well as microvascular thrombi, 
can lead to decreased oxygen diffusing capacity $\left(\mathrm{D}_{\mathrm{LO} 2}\right)$ and the development of arterial hypoxemia. It has been shown that in severe ARDS, there occurs alveolar and interstitial edema resulting from increased permeability of endothelial and alveolar epithelial barriers of pulmonary capillaries, causing infiltration of fluid rich in protein and immune cells into the parenchyma [58]. Fluid accumulation in the alveoli, impaired surfactant synthesis promoting alveolar collapse-all these events reduce the efficiency of gas exchange between the alveoli and vasculature, leading to alveolar hypoxia and hypoxemia [59]. Therefore, microvascular endothelial damage and dysfunction of some alveoli are also the factors that positively correlate with the development of hypoxemia, particularly in severely ill patients with lower respiratory tract lesions.

Some authors consider oxidative stress as one of the possible factors of severe COVID-19 [60]. The relationship has been established between inflammation and oxidative stress [61], but many issues concerned with the degree of oxidative stress involvement in the cytokine storm have not yet been sufficiently studied. Meanwhile, it is suggested that COVID-19 may entail the dysfunction of both endothelial and platelet mitochondria, which may influence thrombosis [62].

Computer simulations have only provided tentative data on the mechanism of SARS-CoV-2 impact directly on the hemoglobin heme group $[7,63]$. It is hypothesized that SARS-CoV-2 does not interact with erythrocytes directly, but affects them through an additional receptor CD147. Molecular analysis of the SARS-CoV-2 structure showed that ORF8 protein and surface glycoprotein of the virus can bind to porphyrin, while ORF1ab, ORF10 and ORF3a proteins can interact with the 1- $\beta$ chain of hemoglobin resulting in dissociation of iron and porphyrin molecules. Dysfunctional hemoglobin deprived of iron atoms is unable to perform the gas-transporting function $\left(\mathrm{O}_{2}\right.$ and $\mathrm{CO}_{2}$ transport $)$, leading to a reduced efficiency of gas exchange and aggravated hypoxia $[64,65]$.

As for the causes of hypoxemia without dyspnea manifestation, not all authors mention that "silent" hypoxemia can occur not only in COVID-19, but also in patients with atelectasis, intrapulmonary or intracardiac shunt [66]. As is known, the adequacy of gas exchange depends primarily on ventilation-perfusion relationships, i.e. the balance between capillary blood flow and pulmonary ventilation. As some authors rightly point out, the key factor of hypoxemia development at an early stage of SARS-CoV-2 infection is a mismatch between the ventilation-perfusion ratio $(\mathrm{V} / \mathrm{Q})$ and the presence of anatomic arteriovenous anastomoses or alveolar shunts in the lungs [67-71]. Right-to-left shunting implies the passage of part of venous blood through a shunt, bypassing ventilated areas of the lungs. Thus, with increased fraction of the pulmonary shunt fraction, hypoxemia results from partial discharge of unoxygenated venous blood (venous admixture) into the arterial bed [69]. An intrapulmonary right-to-left shunt has been demonstrated during contrast echocardiography in a patient with COVID-19 [72], when shunting was accompanied by hypoxia and a corresponding increase in lung ventilation. However, in the presence of a shunt, hyperventilation did not increase $\mathrm{PaO}_{2}$, but decreased $\mathrm{PaCO}_{2}$, since $\mathrm{CO}_{2}$ has higher diffusion capacity than $\mathrm{O}_{2}$. Consequently, in this case, hypocapnia can develop without an increase in ventilation, which accounts for the absence of dyspnea in hypoxemia. In the case of aggravating ARDS severity with progressing hypoxemia and increasing $\mathrm{PaCO}_{2}$, dyspnea with corresponding manifestations of respiratory discomfort may probably develop.

In conclusion, it is worth mentioning that this review article was focused on the analysis of some mechanisms of hypoxemia in ARDS, caused by a new coronavirus infection SARS-CoV-2. The factors described herein are links of the same chain and are of crucial importance for the development of hypoxemia in COVID-19. Obviously, SARS-CoV-2 neuroinvasion into the peripheral and central respiratory chemoreceptors comes to the forefront. The further development of disorders results from a complex influence of the endothelial damage in the lung microcirculatory bed, massive alveolar lesion, impaired hemoglobin molecules, etc. However, according to many authors, the leading role in the development of hypoxemia in the absence of dyspnea belongs to intrapulmonary shunting. Further studies will 
hopefully reveal additional mechanisms of hypoxemia development and its involvement in the pathogenesis of COVID-19.

\section{FUNDING}

This work was supported by the Federal budget within a governmental assignment to the Pavlov Institute of Physiology.

\section{CONFLICT OF INTEREST}

The authors declare that they have no conflict of interest related to the publication of this article.

\section{REFERENCES}

1. Cao Y, Hiyoshi A, Montgomery S (2020) COVID-19 case-fatality rate and demographic and socioeconomic influencers: worldwide spatial regression analysis based on country-level. Data BMJ Open 10(11):e043560. https://doi.org/ 10.1136/bmjopen-2020-043560

2. Franks TJ, Chong PY, Chui P, Galvin JR, Lourens RM, Reid AH, Selbs E, Mcevoy PL, Hayden DL, Fukuoka J, Taubenberger JK, Travis WD (2003) Lung pathology of severe acute respiratory syndrome (SARS): a study of 8 autopsy cases from Singapore. Hum Pathol 34:743-748. https://doi.org/10.1016/S0046-8177(03)00367-8

3. Gilbert JA (2018) Advancing towards precision medicine in ARDS. Lancet Respir Med 6:494$495 . \quad$ https://doi.org/10.1016/S22132600(18)30156-5

4. Li S, Fu B, Meshram CD (2019) Innate immune and inflammatory responses to respiratory viruses. Mediators Inflamm 1-2. https://doi.org/10.1155/ 2019/3146065

5. Azkur AK, Akdis M, Azkur D, Sokolowska M, Van De Veen W, Bruggen MC, O’Mahony L, Gao Y, Nadeau K, Akdis AC (2020) Immune response to SARS-CoV-2 and mechanisms of immunopathological changes in COVID-19. Allergy 75:1564-1581. https://doi.org/10.1111/ all.14364

6. Behrens EM, Koretzky GA (2017) Review: Cytokine storm syndrome: Looking toward the precision medicine era. Arthritis \& Rheumatology 69(6):1135-1143. https://doi.org/10.1002/ art. 40071

7. Liu W, Hualan L (2020) COVID-19: Attacks the 1-Beta chain of hemoglobin and captures the porphyrin to inhibit human heme metabolism.
ChemRxiv Epub ahead of print. https://doi.org/ 10.26434/chemrxiv.11938173.v9

8. Sun X, Wang T, Cai D, Hu Z, Chen J, Liao H, Zhi L, Wei H, Zhang Z, Qiu Y, Wang J, Wang A (2020) Cytokine storm intervention in the early stages of COVID-19 pneumonia. Cytokine Growth Factor Rev 53:38-42. https://doi.org/ 10.1016/j.cytogfr.2020.04.002

9. Zhang $\mathrm{H}$, Penninger JM, Li Y, Zhong $\mathrm{N}$, Slutsky AS (2020) Angiotensin-converting enzyme 2 (ACE2) as a SARS-CoV-2 receptor: molecular mechanisms and potential therapeutic target. Intensive Care Med 46(4):586-590. https:// doi.org/10.1007/s00134-020-05985-9

10. Abdin SM, Elgendy SM, Alyammahi SK, Alhamad DW, Omar HA (2020) Tackling the cytokine storm in COVID-19, challenges and hopes. Life Siences 257:118054. https://doi.org/10.1016/ j.lfs. 2020.118054

11. Xie J, Covassin N, Fan Z, Singh P, Gao W, Li G, Kara T, Somers VK (2020) Association between hypoxemia and mortality in patients with COVID-19. Mayo Clin Proc 95:1138-1147. https://doi.org/10.1016/j.mayocp.2020.04.006

12. Shang J, Wan Y, Luo C, Ye G, Geng Q, Auerbach A, Li F (2020) Cell entry mechanisms of SARS-CoV-2. Proc Natl Acad Sci USA 117(21):11727-11734. https://doi.org/10.1073/ pnas. 2003138117

13. Letko M, Marzi A, Munster V (2020) Functional assessment of cell entry and receptor usage for SARS-CoV-2 and other lineage B betacoronaviruses. Nat Microbiol 5:562-569. https://doi.org/ 10.1038/s41564-020-0688-y

14. Wan Y, Shang J, Graham R, Baric RS, Li F (2020) Receptor recognition by the novel coronavirus from Wuhan: An analysis based on decadelong structural studies of SARS coronavirus. J Virol 94:00127-20. https://doi.org/10.1128/ JVI.00127-20

15. Chuchalin AG (2004) Severe acute respiratory syndrome. Therapeutic Archiv 79(3):5-11. (In Russ).

16. Kuba K, Imai Y, Rao S, Gao H, Guo F, Guan B, Huan Y, Yang P, Zhang Y, Deng W, Bao L, Zhang B, Liu G, Wang Zh, Chappell M, Liu Y, Zheng D, Leibbrandt A, Wada T, Slutsky AS, Liu D, Qin C, Jiang C, Penninger JM (2005) A crucial role of angiotensin converting enzyme 2 (ACE2) in SARS coronavirus-induced lung injury. Nat Med 11(8):875-879. https://doi.org/ $10.1038 / \mathrm{nm} 1267$

17. Cameron MJ, Bermejo-Martin JF, Danesh A, Muller MP, Kelvin DJ (2008) Human immuno- 
pathogenesis of severe acute respiratory syndrome (SARS). Virus Res 133(1):13-19. https://doi.org/ 10.1016/j.virusres.2007.02.014

18. Jiang Y, Xu J, Zhou C (2005) Characterization of cytokine/chemokine profiles of severe acute respiratory syndrome. Am J Respir Crit Care Med 171(8):850-857. https://doi.org/10.1164/ rccm.200407-857OC

19. Huang C, Wang Y, Li X, Ren L, Zhao J, Hu Y, Zhang L, Fan $\mathrm{G}, \mathrm{Xu} \mathrm{J}, \mathrm{Gu} \mathrm{X}$, Cheng $\mathrm{Z}$, Yu T, Xia J, Wei Y, Wu W, Xie X, Yin W, Li H, Liu M, Xiao Y, Gao H, Guo L, Xie J, Wang G, Jiang R, Gao Z, Jin Q, Wang J, Cao B (2020) Clinical features of patients infected with 2019 novel coronavirus in Wuhan, China. Lancet 395:497-506. https://doi.org/10.1016/S0140-6736(20)30183-5

20. Varga Z, Flammer AJ, Steiger P, Haberecker M, Anermatt R, Zinkernagel A, Mehra MR, Schuepbach RA, Ruschitzka F (2020) Endothelial cell infection and endotheliitis in COVID-19. Lancet 395:1417-1418. https://doi.org/10.1016/S01406736(20)30937-5

21. Bhattacharya S, Agarwal S, Shrimali N, Guchhai P (2021) Interplay between hypoxia and inflammation contributes to the progression and severity of respiratory viral diseases. Mol Aspects Med 19:101000. https://doi.org/10.1016/ j.mam.2021.101000

22. Tobin MJ (2020) Basing respiratory management of coronavirus on physiological principles. Am J Respir Crit Care Med 201(11):1319-1320. https:// doi.org/10.1164/rccm.202004-1076ED

23. Dhont S, Eric Derom E, Braeckel EV, Depuydt P, Lambrecht BN (2020) The pathophysiology of "happy" hypoxemia in COVID-19. Respirat Res 21:198. https://doi.org/10.1016/ j.mam.2021.101000

24. Bein T, Grasso S, Moerer O, Quintel M, Guerin C, Deja M, Brondani M, Mehta S (2016) The standard of care of patients with ARDS: ventilatory settings and rescue therapies for refractory hypoxemia. Intensive Care Med 42:699-711. https://doi.org/10.1007/s00134-016-4325-4

25. Wilkerson RG, Adler JD, Shah NG, Brown R (2020) Silent hypoxia: a harbinger of clinical deterioration in patients with COVID-19. Am J Emerg Med 38(10):2243. https://doi.org/10.1016/ j.ajem.2020.05.044

26. Levitan R (2020) The infection that's silently killing coronavirus patients. The New York Times Apr 20.

27. Philip K, Bennett B, Fuller S, Lonergan B, McFadyen C, Burns J, Tidswell R, Vlachou A (2020) Working accuracy of pulse oximetry in
COVID-19 patients stepping down from intensive care: a clinical evaluation. BMJ Open Respir Res 7(1):000778. https://doi.org/10.1136/bmjresp2020-000778

28. Roe PG, Jones JG (1993) Analysis of factors which affect the relationship between inspired oxygen partial pressure and arterial oxygen saturation. Br J Anaesth 71:488-494. https://doi.org/ $10.1093 / \mathrm{bja} / 71.4 .488$

29. Hamilton C, Steinlechner B, Gruber E, Simon P, Wollenek G (2004) The oxygen dissociation curve: quantifying the shift. Perfusion 19:141144. https://doi.org/10.1191/0267659104pf734oa

30. Woyke S, Rauch S, Strohle M, Gatterer H (2021) Modulation of $\mathrm{Hb}-\mathrm{O}_{2}$ affinity to improve hypoxemia in COVID-19 patients. Clin Nutr 40:38-39. https://doi.org/10.1016/j.clnu.2020.04.036

31. Ottestad W, Seim M, Mæhlen JO (2020) COVID19 with silent hypoxemia. Tidsskr Den Nor Laegeforening $140 . \quad \mathrm{https}$ //doi.org/10.4045/ tidsskr.20.0299

32. Couzin-Frankel J (2020) The mystery of the pandemic's "happy hypoxia". Science 368(6490):455-456. https://doi.org/10.1126/science.368.6490.455

33. Gattinoni L, Chiumello D, Rossi S (2020) COVID-19 pneumonia: ARDS or not? Crit Care 24:154-154. https://doi.org/10.1186/s13054020-02880-Z

34. Simonson S, Baker T, Banzett R, Bishop T, Dempsey J, Feldman JL, Guyenet PG, Hodson EJ, Mitchell GS, Moya EA, Nokes BT, Orr JE, Owens RL, Poulin M, Rawling JM, Schmickl CN, Watters JJ, Younes M, Malhotra A (2021) Silent hypoxaemia in COVID-19 patients. J Physiol 599(4):1057-1065. https://doi.org/ 10.1113/JP280769

35. Bhatia P, Mohammed S (2020) Severe Hypoxemia in Early COVID-19 Pneumonia. Am J Respir Crit Care Med 202(4):621-622. https:// doi.org/10.1164/rccm.202004-1313LE

36. Nicholls JM, Poon LL, Lee KC (2003) Lung pathology of fatal severe acute respiratory syndrome. Lancet 361:1773-1778. https://doi.org/ 10.1016/S0140-6736(03)13413-7

37. Tang N, Li D, Wang X, Sun Z (2020) Abnormal coagulation parameters are associated with poor prognosis in patients with novel coronavirus pneumonia. J Thromb Haemost 18:844-847. https:// doi.org/10.1111/jth.14768

38. Liu X, He L, Stensaas L, Dinger B, Fidone S (2009) Adaptation to chronic hypoxia involves immune cell invasion and increased expression of inflammatory cytokines in rat carotid body. Am $\mathbf{J}$ 
Physiol Lung Cell Mol Physiol 296:158-166. https://doi.org/10.1152/ajplung.90597.2008

39. Fung ML (2015) Expressions of angiotensin and cytokine receptors in the paracrine signaling of the carotid body in hypoxia and sleep apnea. Respir Physiol Neurobiol 209:6-12. https://doi.org/ 10.1016/j.resp.2014.09.014

40. Hoffmann M, Kleine-Weber H, Schroeder S, Kruger N, Herrler T, Erichsen S, Schiergens TS, Herrler G, Wu NH, Nitsche A, Muller MA, Drosten C \& Pohlmann S (2020) SARS-CoV-2 cell entry depends on ACE2 and TMPRSS2 and is blocked by a clinically proven protease inhibitor. Cell 181:271-280. https://doi.org/10.1016/ j.cell.2020.02.052

41. Liu B, Li M, Zhou Z, Guan X, Xiang Y (2020) Can we use interleukin-6 (IL-6) blockade for coronavirus disease 2019 (COVID-19)-induced cytokine release syndrome (CRS)? J Autoimmun 111:102452. j.jaut.2020.102452

https://doi.org/10.1016/

42. Manganelli F, Vargas M, Iovino A, Iacovazzo C, Santoro L \& Servillo G (2020) Brainstem involvement and respiratory failure in COVID-19. Neurol Sci 41:1663-1665. https://doi.org/10.1007/ s10072-020-04487-2

43. Schultz HD (2011) Angiotensin and carotid body chemo-reception in heart failure. Curr Opin Pharmacol 11:144-149. https://doi.org/10.1016/ j.coph.2010.12.004

44. Hariri LP, North CM, Shih AR, Israel RA, Maley JH, Villalba JA, Vinarsky V, Rubin J, Okin DA, Sclafani A, Alladina JW, Griffith JW, Gillette MA, Raz Y, Richards CJ, Wong AK, Ly A, Hung YP, Chivukula RR, Petri CR, Calhoun TF, Brenner LN, Hibbert KA, Medoff BD, Hardin CC, Stone JR, Mino-Kenudson M (2021) Lung histopathology in COVID-19 as compared to SARS and H1N1 influenza: a systematic review. Chest 159:73-84. https://doi.org/ 10.1016/j.chest.2020.09.259

45. Mao L, Jin H, Wang M, Hu Y, Chen S, He Q, Chang J, Hong C, Zhou Y, Wang D, Miao X, Li Y, Hu B (2020) Neurologic manifestations of hospitalized patients with coronavirus disease 2019 in Wuhan, China. JAMA Neurol 77:683690. https://doi.org/10.1001/jamaneurol.2020.1127

46. Moriguchi T, Harii N, Goto J, Harada D, Sugawara $\mathrm{H}$, Takamino J, Ueno $\mathrm{M}$, Sakata $\mathrm{H}$, Kondo K, Myose N, Nakao A, Takeda M, Haro H, Inoue O, Suzuki-Inoue K, Kubokawa K, Ogihara S, Sasaki T, Kinouchi H, Kojin H, Ito M, Onishi H, Shimizu T, Sasaki Y, Enomoto N, Ishi- hara $\mathrm{H}$, Furuya $\mathrm{S}$, Yamamoto $\mathrm{T}$, Shimada $\mathrm{S}$ (2020) A first case of meningitis/encephalitis associated with SARS-Coronavirus-2. Int J Infect Dis 94:55-58. https://doi.org/10.1016/ j.ijid.2020.03.062

47. Paniz-Mondolfi A, Bryce C, Grimes Z, Gordon RE, Reidy J, Lednicky J, Sordillo EM, Fowkes M (2020) Central nervous system involvement by severe acute respiratory syndrome coronavirus-2 (SARS-CoV-2). J Med Virol 92: 699702. https://doi.org/10.1002/jmv.25915

48. McCray PB Jr, Pewe L, Wohlford-Lenane C, Hickey M, Manzel L, Shi L, Netland J, Jia HP, Halabi C, Sigmund CD, Meyerholz DK, Kirby P, Look DC, Perlman S (2007) Lethal infection of K18-hACE2 mice infected with severe acute respiratory syndrome coronavirus. $\mathrm{J}$ Virol 81(2):813-821. https://doi.org/10.1128/ JVI.02012-06

49. Netland J, Meyerholz DK, Moore S, Cassell M, Perlman S (2008). Severe acute respiratory syndrome coronavirus infection causes neuronal death in the absence of encephalitis in mice transgenic for human ACE2. J Virol 82:15:7264-7275. https://doi.org/10.1128/JVI.00737-08

50. Li K, Wohlford-Lenane C, Perlman S, Zhao J, Jewell AK, Reznikov LR, Gibson-Corley KN, Meyerholz DK, McCray PB Jr (2016) Middle east respiratory syndrome coronavirus causes multiple organ damage and lethal disease in mice transgenic for human dipeptidyl peptidase 4 . J Infect Dis 213(5):712-722. https://doi.org/10.1093/infdis/jiv499

51. Talbot PJ, Ekandй S, Cashman NR, Mounir S, Stewart JN (1993) Neurotropism of human coronavirus 229E. Adv Exp Med Biol 342:339-346. https://doi.org/10.1007/978-1-4615-2996-5_52

52. Glass WG, Subbarao K, Murphy B, Murphy PM (2004) Mechanisms of host defense following severe acute respiratory syndrome-coronavirus (SARS-CoV) pulmonary infection of mice. J Immunol 173:4030-4039. https://doi.org/ 10.4049/jimmunol.173.6.4030

53. Li YC, Bai WZ, Hirano N, Hayashida T, Hashikawa T (2012) Coronavirus infection of rat dorsal root ganglia: ultrastructural characterization of viral replication, transfer, and the early response of satellite cells. Virus Res 163(2):628-635. https:// doi.org/10.1016/j.virusres.2011.12.021

54. Jia HP, Look DC, Shi L, Hickey M, Pewe L, Netland J, Farzan M, Wohlford-Lenane C, Perlman S, McCray PB Jr (2005) ACE2 receptor expression and severe acute respiratory syndrome coronavirus infection depend on differentiation of 
human airway epithelia. J Virol 79(23):1461414621. https://doi.org/10.1128/JVI.79.23.1461414621.2005

55. Klok FA, Kruip MJHA, van der Meer NJM, Arbous MS, Gommers DAMPJ, Kant KM, Kaptein FHJ, Paassen J, Stals MAM, Huisman MV, Endeman H (2020) Incidence of thrombotic complications in critically ill ICU patients with COVID-19. Thromb Res 191:145147. res.2020.04.013

56. Wichmann D, Sperhake J-P, Lütgehetmann M, Steurer S, Edler C, Heinemann A, Heinrich F, Mushumba H, Kniep I, Schröder AN, Burdelski C, Heer G, Nierhaus A, Frings D, Pfefferle S, Becker $\mathrm{H}$, Bredereke-Wiedling $\mathrm{H}$, Weerth A, Paschen HR, Sheikhzadeh-Eggers S, Stang A, Schmiedel S, Bokemeyer C, Addo MM, Aepfelbacher M, Püschel K, Kluge S, Less S (2020) Autopsy findings and venous thromboembolism in patients with COVID-19: a prospective cohort study. Ann Intern Med 173(4):268-277. https://doi.org/10.7326/M20-2003

57. Eriksson O, Hultström M, Persson B, Lipcsey M, Ekdahl KN, Nilsson B, Frithiof R (2020) Mannose-binding lectin is associated with thrombosis and coagulopathy in critically ill COVID-19 patients. Thrombosis and Haemostasis 120(12):1720-1724. https://doi.org/10.1055/s0040-1715835

58. Lee KY (2017) Pneumonia, acute respiratory distress syndrome, and early immune-modulator therapy. Int J Mol Sci 18:388. https://doi.org/ 10.3390/ijms18020388

59. Sarkar M, Niranjan N, Banyal PK (2017) Mechanisms of hypoxemia. Lung India 34(1):2-15. https://doi.org/10.4103/0970-2113.197116

60. Khomich OA, Kochetkov SN, Bartosch B, Ivanov AV (2018) Redox biology of respiratory viral infections. Viruses 10(8):392. https:// doi.org/10.3390/v10080392

61. Ackermann M, Verleden SE, Kuehnel M, Haverich A, Welte T, Laenger F, Vanstapel A, Werlein C, Stark H, Tzankov A, Li WW, Li VW, Mentzer SJ, Jonigk D (2020). Pulmonary Vascular Endothelialitis, Thrombosis, and Angiogenesis in COVID-19. N Engl J Med 383(2):120-128. https://doi.org/10.1056/NEJMoa2015432

62. Cloonan SM, Choi AM (2016) Mitochondria in lung disease. J Clin Invest 126(3):809-820. https:// doi.org/10.1172/JCI81113

63. Wenzhong L, Hualan L (2020) COVID-19 Disease: ORF8 and surface glycoprotein inhibit heme metabolism by binding to porphyrin. ChemRxiv
Preprint. https://doi.org/10.26434/chemrxiv. 11938173

64. Cavezzi A, Troiani E, Corrao S (2020) COVID19: hemoglobin, iron, and hypoxia beyond inflammation. A narrative review. Clin Pract 10(2):1271. https://doi.org/10.4081/cp.2020.1271

65. Cloonan SM, Choi AM (2016) Mitochondria in lung disease. J Clin Invest 126(3):809-820. https:// doi.org/10.1172/JCI81113

66. Dassios T, Curley A, Morley C, Ross-Russell R (2015) Using measurements of shunt and ventilation-to-perfusion ratio to quantify the severity of bronchopulmonary dysplasia. Neonatology 107(4):283-288. https://doi.org/10.1159/ 000376567

67. D'Alonzo GE, Dantzker DR (1983) Respiratory failure, mechanisms of abnormal gas exchange, and oxygen delivery. Med Clin North Am 67:557571. https://doi.org/10.1016/S00257125(16)31189-0

68. West JB (2008) Respiratory physiology-the essentials. 9th ed. Lippincott Williams\&Wilkins, Baltimore.

69. Ackermann M, Verleden SE, Kuehnel M, Haverich A, Welte T, Laenger F, Vanstapel A, Werlein C, Stark H, Tzankov A, Li WW, Li VW, Mentzer SJ, Jonigk D (2020) Pulmonary vascular endothelialitis, thrombosis, and angiogenesis in COVID-19. N Engl J Med 383:120-128. https:// doi.org/10.1056/NEJMoa2015432

70. Nouri-Vaskeh M, Sharifi A, Khalili N, Zand R, Sharifi A (2020) Dyspneic and non-dyspneic (silent) hypoxemia in COVID-19: possible neurological mechanism. Clin Neurol Neurosurg 198:106217. https://doi.org/10.1016/j.clineuro. 2020

71. Wichmann D, Sperhake J-P, Lütgehetmann M, Steurer S, Edler C, Heinemann A, Heinrich F, Mushumba H, Kniep I, Schröder AN, Burdelski C, Heer G, Nierhaus A, Frings D, Pfefferle $\mathrm{S}$, Becker $\mathrm{H}$, Bredereke-Wiedling $\mathrm{H}$, Weerth A, Paschen HR, Sheikhzadeh-Eggers S, Stang A, Schmiedel S, Bokemeyer C, Addo MM, Aepfelbacher M, Püschel K, Kluge S, Less S (2020) Autopsy findings and venous thromboembolism in patients with COVID-19: a prospective cohort study. Ann Intern Med 173 (4):268-277. https://doi.org/10.7326/M20-2003

72. Mahjoub Y, Rodenstein DO, Jounieaux V (2020) Severe COVID-19 disease: rather AVDS than ARDS? Crit Care 24:327. https://doi.org/ 10.1186/s13054-020-02972-w

Translated by A. Polyanovsky 